NUKHBATUL 'ULUM : Jurnal Bidang Kajian Islam

Vol. 3, No. 1 (2017) : Hal. 12-18

Website: https://journal.stiba.ac.id

ISSN : 2685-7537 (online) 2338-5251 (Printed)

\title{
DAYA SERAP HUKUM ISLAM DI INDONESIA PADA BIDANG PRIVAT
}

\author{
Akrama Hatta \\ Sekolah Tinggi Ilmu Islam dan Bahasa Arab (STIBA) Makassar, \\ Jl. Inspeksi PAM Manggala-Antang Makassar \\ E-Mail : akrama@stiba.ac.id
}

\section{Keywords :}

Syariah, law, hokum, privat

\section{ABSTRACT}

The adaptation of syari'ah law into the Indonesian national legal
system has been one solution offered to accomodate the tendency of
moslem society in adopting the syari'ab law as a controlling system in
various aspects of life specifically the private. This effort is applied by
adopting syari'ah law and transforms it into national legal system
through the constitution and regulation in many aspects. Within the
process, the adopted syari'ah law in the national law affects on many
aspects significantly and is releavant with the plural society model. It
shows that syari'ah law has the chance to be adopted within the
national law aspects.




\section{PENDAHULUAN}

Sistem hukum Indonesia adalah sistem hukum yang berlaku nasional di negara Republik Indonesia.sistem hukum Indonesia tersebut bersifat majemuk, karena sistem hukum yang berlaku nasional terdiri dari lebih satu sistem. Sistem sistem tersebut adalah sistem hukum adat, sistem hukum Islam dan sistem hukum Barat.

Hukum Islam adalah bagian dari agama Islam, sehingga bersifat universal.Pada hakikatnya hukum Islam merupakan keyakinan yang melekat pada setiap orang yang beragama Islam, tidak peduli kapan dan dimanapun.Indonesia adalah negara hukum (rechtstaat), bukan negara kekuasaan (machstaats) sebagaimana tertuang dalam bunyi UUD 1945 pasal 1 ayat (3) bahwa negara Indonesia adalah negara hukum. Sebagai negara hukum, maka menjadi suatu kewajiban bahwa setiap penyelenggaraan negara dan pemerintahannya selalu berdasarkan pada peraturan perundang-undangan.Maka negara hukum yang dimaksud di sini bukan hanya merupakan pengertian umum yang dapat dikaitkan dengan berbagai konotasi.Maupun hanya rechstaat dan rule of law sebagaimana dipraktikkan di Barat.Tapi monokrasi Islam dan negara hukum Pancasila yang dipraktikkan di Indonesia.

Namun, Indonesia bukan negara yang menganut paham teokrasi berdasarkan penyelenggaraan negaranya terhadap agama tertentu saja.Di mana, menurut paham teokrasi, negara dan agama dipahami sebagai dua hal yang tidak dapat dipisahkan.Yakni dijalankan berdasarkan Tuhan.Sehingga tata kehidupan masyarakat, bangsa, dan negara dilakukan dengan titah Tuhan dalam kehidupan umat manusia.Oleh karena itu, paham ini melahirkan konsep negara agama atau agama resmi, dan dijadikannya agama resmi tersebut sebagai hukum positif. Konsep negara teokrasi ini sama dengan paradigma integralistik. Yaitu paham yang beranggapan bahwa agama dan negara merupakan suatu kesatuan yang tidak dapat dipisahkan.

Pada tataran lain, negara Indonesia juga tidak menganut negara sekuler yang mendisparitas agama atas negara dan memisahkan secara diametral antara agama dengan negara. Paham ini melahirkan konsep agama dan negara yang merupakan dua entitas berbeda, dan satu sama lain memiliki wilayah garapan masing-masing. Sehingga, keberadaannya harus dipisahkan dan tidak boleh satu sama lain melakukan intervensi.

Berdasarkan pendahuluan di atas, maka penulis membatasi pembahasan ini pada beberapa poin berikut

1. Bagaimana Epistimologi Hukum Islam dan Hukum Privat Islam ?

2. Bagaimana Peluang dan Tantangan Hukum Islam di Indonesia pada Fase-fase yang dilaluinya.

\section{PEMBAHASAN}

\section{A. Epistimologi Hukum Islam dan Hukum Privat Islam}

"Hukum Islam" merupakan terminologi khas Indonesia, jikalau diterjemahkan langsung kedalam bahasa Arab maka akan diterjemahkan menjadi al-bukmu al-Islämi, suatu terminologi yang tidak dikenal dalam al-Qur'an dan al-Sunnah. Maka 
padanan yang tepat dari istilah "Hukum Islam" adalah al-fiqh alIslāmiatau al-Syarìab al-Islämiyyah, sedangkan dalam wacana ahli hukum barat digunakan istilah Islamic law. ${ }^{1}$

$$
\text { Sedangkan terminologi }
$$

"Hukum privat Islam" yang menjadi telaah utama makalah ini dapat diuraikan bardasarkan pengertian dari kata-kata penyusunnya, sebagai berikut

Hukum, adalah seperangkat peraturan-peraturan yang dibuat oleh yang berwenang (negara), dengan tujuan mengatur tata kehidupan bermasyarakat, yang mempunyai ciri memerintah dan melarang serta mempunyai sifat memaksa, serta mengikat anggotanya, dengan menjatuhkan sanksi hukuman bagi mereka yang melanggarnya. ${ }^{2}$

Sedangkan Hukum privat, adalah hukum yang bertujuan menjamin adanya kepastian didalam hubungan antara orang yang satu dengan orang yang lain kedua-duanya sebagai anggota masyaraka ${ }^{3}$ dan benda dalam masyarakat. Dalam terminologi Islam istilah perdata ini sepadan dengan pengertian mua'amalah.

Kemudian frase Hukum privat disandarkan kepada kata Islam, Jadi dapat dipahami menurut hemat penulis bahwa "Hukum Perdata Islam" adalah peraturan yang dirumuskan berdasarkan wahyu Allah swt dan sunnah Rasulullah saw tentang tingkah laku mukallaf dalam hal perdatamu'amalah yang diakui dan

${ }^{1}$ Ahmad Rofiq, Hukum Islam di Indonesia(Cet. I, Jakarta: Rajawali Pers, 2003), h. 3.

${ }^{2}$ Soeroso, Pengantar IImu Hukum (Cet. I, Jakarta: Sinar Grafika,2004), h. 38.

${ }^{3}$ Soeroso, Pengantar Ilmu Hukum, h. 200 diyakini berlaku mengikat bagi semua pemeluk Islam (di Indonesia).

Menurut Muhammad Daud Ali, ${ }^{4}$ "Hukum Perdata Islam" adalah sebagian dari hukum Islam yang telah berlaku secara yuridis formal atau menjadi hukum positif dalam tata hukum Indonesia, yang isinya hanya sebagian dari lingkup mu'amalah, bagian hukum Islam ini menjadi hukum positif berdasarkan atau karena ditunjuk oleh peraturan perundang-undangan. Contohnya adalah hukum perkawinan, kewarisan, wasiat, hibah, zakat dan perwakafan.

\section{B. Peluang dan Tantangan Hukum Islam di Indonesia dari Masa ke Masa}

1. Hukum Islam Pada Masa Kerajaan/kesultanan Islam di Nusantara ${ }^{5}$

Pada masa ini hukum Islam dipraktekkan oleh masyarakat dalam bentuk yang hampir bisa dikatakan sempurna (syumul), mencakup masalah mu'amalah, ahwal al-syakhsiyyah (perkawinan, perceraian dan warisan), peradilan, dan tentu saja dalam masalah ibadah.

Hukum Islam juga menjadi sistem hukum mandiri yang digunakan di kerajaan-kerajaan Islam nusantar. Tidaklah berlebihan jika dikatakan pada masa jauh sebelum penjajahan belanda, hukum islam menjadi hukum yang positif di nusantara.

${ }^{4}$ Tim Penyusun, Bunga Rampai Peradilan Islam di Indonesia Jilid 1, (Bandung: Ulul Albab Pres, 1997), h. 73

${ }^{5}$ Amiur Nurudin dan Azhari A Tarigan, Hukum Perdata Islam dilndonesia, (Jakarta: Kencana, 2004), h. 8 


\section{Hukum Islam Pada Masa Penjajahan Belanda \\ Perkembangan hukum Islam} di Indonesia pada masa penjajahan Belanda dapat diklasifikasi kedalam dua bentuk, Pertama, adanya toleransi pihak Belanda melalui VOC yang memberikan ruang agak luas bagi perkembangan hukum Islam. Kedua, adanya upaya intervensi Belanda terhadap hukum Islam dengan menghadapkan pada hukum adat.

Pada fase kedua ini Belanda ingin menerapkan politik hukum yang sadar terhadap Indonesia, yaitu Belanda ingin menata kehidupan hukum di Indonesia dengan hukum Belanda, dengan tahap-tahap kebijakkan strategiknya yaitu:

-Receptie in Complexu (Salomon Keyzer \& Christian Van Den Berg [1845-1927]), teori ini menyatakan hukum menyangkut agama seseorang. Jika orang itu memeluk Islam maka hukum Islamlah yang berlaku baginya, namum hukum Islam yang berlaku tetaplah hanya dalam masalah hukum keluarga, perkawinan dan warisan.

$$
\text { Teori Receptie ( Snouck }
$$

Hurgronje [1857-1936] disistemisasi oleh C. Van Vollenhoven dan Ter Harr Bzn), teori ini menyatakan bahwa hukum Islam baru diterima memiliki kekuatan hukum jika benar-benar diterima oleh hukum adat, implikasi dari teori ini mengakibatkan perkembangan dan pertumbuhan hukum Islam menjadi lambat dibandingkan institusi lainnya ${ }^{6}$ di nusantara.

3. Hukum Islam bidang privat pada masa penjajahan jepang

\footnotetext{
${ }^{6}$ Amiur Nurudin dan Azhari A Tarigan, Hukum Perdata Islam dilndonesia, h. 14

${ }^{7}$ Amiur Nurudin dan Azhari A Tarigan, Hukum Perdata Islam dilndonesia, h. 14
}

Menurut Daniel S. Lev Jepang memilih untuk tidak mengubah atau mempertahankan beberapa peraturan yang ada. Adat istiadat lokal dan praktik keagamaan tidak dicampuri oleh Jepang untuk mencegah resistensi, perlawanan dan oposisi yang tidak diinginkan.

Jepang hanya berusaha menghapus simbol-simbol pemerintahan Belanda di Indonesia, dan pengaruh kebijakan pemerintahan Jepang terhadap perkembangan hukum di indonesia tidak begitu signifikan.

\section{Masa Kemerdekaan}

\section{Hukum Islam Pada}

Salah satu makna terbesar kemerdekaan bagi bangsa Indonesia adalah terbebas dari pengaruh hukum Belanda, menurut Prof. Hazairi, ${ }^{8}$ setelah kemerdekaan, walaupun aturan peralihan UUD 1945 menyatakan bahwa hukum yang lama masih berlaku sepanjang tidak bertentangan dengan UUD 1945, seluruh peraturan pemerintahan Belanda yang berdasar teori receptie (Hazairin menyebutnya sebagai teori iblis) tidak berlaku lagi karena jiwanya bertentangan dengan UUD 1945.

Teori receptie harus exit karena bertentangan dengan al-Qur'an dan sunnah Rosul. Disamping Hazairin, Sayuti Thalib juga mencetuskan teori Receptie aContrario, yang menyatakan bahwa hukum adat baru berlaku kalau tidak bertentangan dengan hukum Islam. ${ }^{\text {? }}$

\section{Hukum Islam Pada} Masa Pemerintahan Orde Baru

Pada awal orde baru berkuasa ada harapan baru bagi dinamika

\footnotetext{
${ }^{8}$ Amiur Nurudin dan Azhari A Tarigan, Hukum Perdata Islam dilndonesia, h. 17-19

${ }^{9}$ Ahmad Rofiq, Hukum Islam di Indonesia, h. 20
} 
perkembangan hukum Islam, harapan ini timbul setidaknya karena kontribusi yang cukup besar yang diberikan umat Islam dalam menumbangkan rezim orde lama. Namun pada realitasnya keinginan ini menurut DR. Amiiur Nurudin bertubrukan denagn strategi pembangunan orde baru, yaitu menabukan pembicaraan masalahmasalah ideologis selain Pancasila terutama yang bersifat keagamaan.

Namun dalam era orde baru ini banyak produk hukum Islam (tepatnya Hukum Perdata Islam) yang menjadi hukum positif yang berlaku secara yuridis formal, walaupun didapat dengan perjuangan keras umat Islam. Diantaranya oleh Ismail Sunny ${ }^{10}$ coba diskrisipsikan secara kronologis berikut ini :

a. Undang- undang Nomor 1 tahun 1974 tentang Perkawinan

Politik hukum memberlakukan hukum Islam bagi pemeluk-pemeluknya oleh pemerintah orde baru, dibuktikan oleh UU ini, pada pasal 2 diundangkan "Perkawinan adalah sab apabila dilakukan menurut bukum masing-masing agama dan kepercayaan itu" dan pada pasal 63 dijelaskan bahwa yang dimaksud dengan pengadilan dalam UU ini adalah Pengadilan Agama (PA) bagi agama Islam dan Pengadilan Negeri (PN) bagi pemeluk agama lainnya.

Dengan UU No. 1 tahun 1974 Pemerintah dan DPR memberlakukan hukum Islam bagi pemeluk-pemeluk Islam dan menegaskan bahwa Pengadilan Agama berlaku bagi mereka yang beragama Islam.

b. Undang- undang Nomor 7 tahun 1989 tentang Peradilan Agama
Dengan disahkanya UU PA tersebut, maka terjadi perubahan penting dan mendasar dalam lingkungan PA. Diantaranya:

1. PA telah menjadi peradilan mandiri, kedudukannya benar-benar telah sejajar dan sederajat dengan peradilan umum, peradilan militer, dan peradilan tata usaha negara.

2. Nama, susunan, wewenang, kekuasaan dan hukum acaranya telah sama dan seragam diseluruh Indonesia. Dengan univikasi hukum acara PA ini maka memudahkan terjadinya ketertiban dan kepastian hukum dalam lingkungan PA.

3. Terlaksananya ketentuanketentuan dam UU Pokok Kekuasaan Kehakiman 1970.

4. Terlaksanya pembangunan hukum nasional berwawasan nusantara dan berwawasab Bhineka Tunggal ika dalam UU PA.

c. Kompilasi Hukum Islam Inpres no. 1 tahun 1991 (KHI)

Seperti diuraikan diawal makalah ini bahwa sejak masa kerajaankerajan Islam di nusantara, hukum Islam dan peradilan agama telah eksis. Tetapi hakim-hakim agama diperadilan tersebut sampai adanya KHI tidak mempunyai kitab hokum khusus sebagai pegangan dalam memecahkan kasus-kasus yang mereka hadapi.

Dalam menghadapi kasuskasus itu hakim-hakim tersebut merujuk kepada kitab-kitab fiqh yang puluhan banyaknya. Oleh karena itu sering terjadi dua kasus serupa apabila ditangani oleh dua orang hakim yang berbeda referensi kitabnya, keputusannya dapat berbeda pula,

${ }^{10}$ Tim Penyusun, Bunga Rampai

Peradilan Islam di Indonesia Jilid , h. 43-47 
sehingga menimbulkan ketidakpastian hukum.

Guna mengatasi ketidakpastian hukum tersebut pada Maret 1985 Presiden Soeharto mengambil prakarsa sehigga terbitlah Surat Keputusan Bersama (SKB) Ketua Makamah Agung dan Departemen Agama.SKB itu membentuk proyek kompilasi hukum islam dengan tujuan merancang tiga buku hukum, masing-masing tentang Hukum perkawinan (Buku I), tentang Hukum Kewarisan (Buku II), dan tentang Hukum Perwakafan (BUKU III)

Bulan Februari 1988 ketiga buku itu dilokakaryakan dan mendapat dukungan luas sebagai inovasi dari para ulama di seluruh Indonesia. Pada tanggal 10 Juni 1991 Suharto menandatangani Intruksi Presiden No. 1 tahun 1991 sebagai dasar hukum berlakunya KHI tersebut.

Oleh karena itu sudah jelas bahwa dalam bidang perkawinan, kewarisan dan wakaf bagi pemelukpemeluk Islam telah ditetapkan oleh undang-undang yang berlaku adalah hukum Islam.

\section{Hukum Islam Pada}

\section{Masa Reformasi}

Era reformasi dimana iklim demokrasi di Indonesia membaik dimana tidak ada lagi kekuasaan repsesif seperti era orde baru, dan bertambah luasnya keran-keran aspirasi politik umat Islam pada pemilu 1999, dengan bermunculannya partai-partai Islam dan munculnya tokoh-tokoh politik Islam dalam kancah politik nasional sehingga keterwakilan suara umat Islam bertambah di lembaga legislatif maupun eksekutif.

Mereka giat memperjuangkan aspirasi umat Islam terrmasuk juga memperjuangkan bagaimana hukum
Islam ikut juga mewarnai proses pembanguanan hukum nasional.

\section{PENUTUP}

Hukum Islam merupakan sinonim kata al-Syariah al-Islamiyyah, sedangkan hukum privat Islam atau hukum Perdata Islam merupakan peraturan yang dirumuskan berdasarkan wahyu Allah swt dan sunnah Rasulullah saw tentang tingkah laku mukallaf dalam hal perdata mu'amalab yang diakui dan diyakini berlaku mengikat bagi semua pemeluk Islam (diIndonesia). Hukum Islam di Indonesia telah mengalami pasang surut seiring dengan kebijakan yang diterapkan oleh pemerintah. Pasang surut tersebut adalah perkembangan yang dinamis dan berkesinambungan bagi upaya transformasi hukum Islam ke dalam sistem hukum Nasional. Sejarah produk hukum Islam sejak masa penjajahan hingga masa kemerdekaan dan masa reformasi merupakan fakta yang menjadi bukti bahwa sejak dahulu kala hukum Islam telah menjadi hukum yang sangat

\section{DAFTAR PUSTAKA}

Ali, Muhammad Daud, Penerapan Hukum Islam dalam Negara Republike Indonesia, Makalah disampaikan pada Pendidikan Kader Ulama di Jakarta, tanggal 17 Mei 1995. Nurudin, Amiur dan A Tarigan ,Hukum Perdata Islam diIndonesia, Jakarta: Kencana, 2004

Didi Kusnadi. Hukum Islam di Indonesia (Tradisi, Pemikiran, Politik Hukum dan

Produk Hukum). Kuningan: Ebook, 2010. 
Website: https://journal.stiba.ac.id

ISSN : 2685-7537 (online) 2338-5251 (Printed)

Rafiq, Ahmad, Hukum Islam di Indonesia (Cet I; Jakarta: PT. Raja Grafindo Persada, 1995)

Rasdiyanah, Andi, Kontribusi Hukum Islam dalam Mewujudkan Hukum Pidana Nasional, Makalah Disampaikan pada upacara Pembukaan Seminar Nasional tentang Kontribusi Hukum Islam Terhadap Terwujudnya Hukum Pidana Nasional yang Beriiwa Kebangsaan, UII-Yogyakarta, 2 Desember 1995.

Rofiq, Ahmad, Hukum Islam di Indonesia, Jakarta: Rajawali Pers, 2003

Soeroso, Pengantar Ilmu Hukum, Jakarta: sinar grafika, 2004

Speyoeti, Zarkowi, Kontribusi Hukum Islam Terbadap Hukum Nasional, Makalah disampaikan pada Seminar Konsep Keadilan dalam Perspektif Hukum, IAIN Sunan Ampel Gunungjati-Bandung, 16 Mei 1994.

Subekti, Asas-Asas Hukum Perdata, Jakarta: Intermasa, 2005

Tim Penyusun, Bunga Rampai Peradilan Islam di Indonesia Jilid 1, Bandung: Ulul Albab Pres, 1997

Tim Penyusun, Peradilan Agama di Indonesia; Sejarah Perkembangan Lembaga dan Proses Pembentukkan UndangUndangnya, Jakarta DEPAG, 2001

http://sesukakita.wordpress.com/201 1/07/10/kedudukan-hukumislam-dalam-negara-republikindonesia/

http://regafelix.wordpress.com/2012 03/25/perkembangan-dankedudukan-hukum-islamdalam-sistem-hukumnasional// 